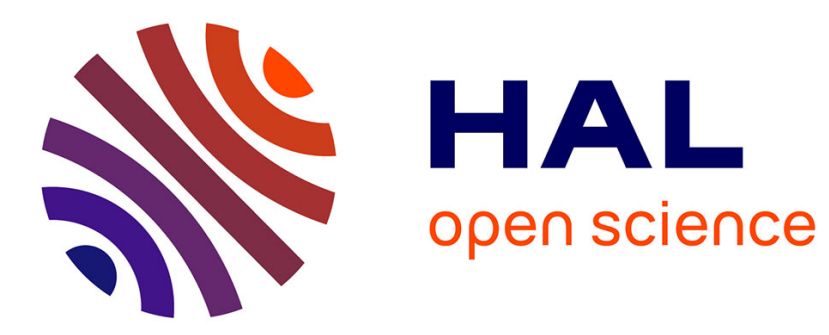

\title{
Low concentration thresholds of plasma membranes for rapid energy-independent translocation of a cell penetrating peptide
}

Catherine L. Watkins, Dirk Schmaljohann, Shiroh Futaki, Arwyn T. Jones

\section{- To cite this version:}

Catherine L. Watkins, Dirk Schmaljohann, Shiroh Futaki, Arwyn T. Jones. Low concentration thresholds of plasma membranes for rapid energy-independent translocation of a cell penetrating peptide. Biochemical Journal, 2009, 420 (2), pp.179-189. 10.1042/BJ20090042 hal-00479146

\section{HAL Id: hal-00479146 https://hal.science/hal-00479146}

Submitted on 30 Apr 2010

HAL is a multi-disciplinary open access archive for the deposit and dissemination of scientific research documents, whether they are published or not. The documents may come from teaching and research institutions in France or abroad, or from public or private research centers.
L'archive ouverte pluridisciplinaire HAL, est destinée au dépôt et à la diffusion de documents scientifiques de niveau recherche, publiés ou non, émanant des établissements d'enseignement et de recherche français ou étrangers, des laboratoires publics ou privés. 
Low concentration thresholds of plasma membranes for rapid energy-independent translocation of a cell penetrating peptide.

Catherine L. Watkins ${ }^{*}$, Dirk Schmaljohann ${ }^{*}$, Shiroh Futaki ${ }^{\dagger}$, Arwyn T. Jones ${ }^{* 1}$

*Welsh School of Pharmacy, Cardiff University, Cardiff, CF10 3NB, Wales, United Kingdom, ${ }^{\dagger}$ Institute for Chemical Research, Kyoto University, Uji, Kyoto 611-0011, Japan.

${ }^{1}$ To whom correspondence should be addressed (email jonesat@cardiff.ac.uk).

Running Title: Direct translocation of the cell penetrating peptide octaarginine across the plasma membrane.

Keywords: Cell penetrating peptides, cholesterol, endocytosis, fluorescence microscopy, methyl-ß-cyclodextrin, octaarginine,

Abbreviations used: $\mathrm{CPP}$, cell penetrating peptide; $\mathrm{M} \beta \mathrm{CD}$, methyl- $\beta$-cyclodextrin; M $\beta C D$ :Chol, methyl- $\beta$-cyclodextrin:cholesterol complex; PBS, phosphate buffered saline; PI, propidium iodide; $\mathrm{R}_{\mathrm{L}} 8$, octaarginine; $\mathrm{SFM}$, serum free medium; $\mathrm{Tf}$, transferrin. 


\begin{abstract}
The exact mechanisms by which cell penetrating peptides such as oligoarginines and penetratin cross biological membranes has yet to be elucidated, but this is required if they are to reach their full potential as cellular delivery vectors. Here, qualitative and quantitative analysis of the influence of temperature, peptide concentration and plasma membrane cholesterol on the uptake and subcellular distribution of the model cell penetrating peptide octaarginine was performed in a number of suspension and adherent cell lines. When experiments were performed on ice, the peptide at $2 \mu \mathrm{M}$ extracellular concentration efficiently entered and uniformly labelled the cytoplasm of all the studied suspension cells but a ten-fold higher concentration was required to observe similar results in adherent cells. At $37^{\circ} \mathrm{C}$ and at higher peptide concentrations, time-lapse microscopy experiments showed that the peptide rapidly translocated the entire plasma membrane of suspension cells, with no evidence of a requirement for nucleation zones to promote this effect. Cholesterol depletion with methyl- $\beta$-cyclodextrin enhanced translocation of octaarginine across the plasma membrane of suspension cells at $37^{\circ} \mathrm{C}$ but decreased overall peptide accumulation. Under the same conditions in adherent cells this agent had no effect on peptide uptake or distribution. Cholesterol depletion increased the overall accumulation of the peptide at $4^{\circ} \mathrm{C}$ in $\mathrm{KGla}$ cells, but this effect could be reversed by re-addition of cholesterol as methyl- $\beta$-cyclodextrincholesterol complexes. The results highlight the relatively high porosity of the plasma membrane of suspension cells to this peptide, especially at low temperatures, suggesting this feature could be exploited for delivering bioactive entities.
\end{abstract}




\section{INTRODUCTION}

Cell penetrating peptides (CPPs) or protein transduction domains have now been described for two decades $[1,2]$. During this period several different CPP classes have been described that contain a variety of sequences and electrostatic charges, but all show a common ability to traverse biological membranes [3]. The best characterised include peptides rich in basic residues arginine and lysine such as the HIV-Tat peptide and synthetic oligoarginines (R6R18) [4]. Much of the interest in CPPs stems from their proven ability to not only traverse membranes but to also act as delivery vectors, in vitro and vivo, for bioactive macromolecules with therapeutic potential such as siRNA, plasmids, peptide nucleic acids and proteins [5-7]. The precise mechanisms employed by CPPs to translocate through biological membranes is still largely unknown, and as different classes of CPPS exist it is unlikely that a single model will emerge to cover all the different classes. Translocation was initially believed to be mediated by endocytosis, a notion that was then superseded with the finding that cellular uptake was independent of temperature, receptor and energy $[8,9]$. In the wake of findings that fixation of cells was responsible for significant artefacts relating to uptake and localisation $[10,11]$, the concept of an endocytic uptake mechanism gained stronger prominence as the primary route for cellular CPP entry [12-15]. More recent data, however, suggest that the fraction of peptide that gains access to cells directly through the plasma membrane, rather than via endocytosis, is highly dependent on the extracellular peptide concentration and the presence of serum in the growth media [16-20]. These studies relate mostly to cationic variants such as HIV-Tat and oligoaarginines.

Our previous studies showed that two leukaemia cell lines, KG1a and K562 were porous to both HIV-TAT peptide and octaarginine (R8) when relatively low concentrations of the peptides $(\leq 2 \mu \mathrm{M})$ was incubated with the cells on ice $\left(4^{\circ} \mathrm{C}\right)[21]$. As expected no endocytic vesicles were observed, rather the labelling was diffuse in the cytosol, the nucleus and in the case of the D-form of R8, enriched in the nucleolus. Cytosolic diffusion and nuclear accumulation of the D-form of $\mathrm{R} 8$ peptide was also reported with incubations at $4^{\circ} \mathrm{C}$ in adherent HeLa cells [22] and uptake of RRRRRRRW, was found to be higher at $4^{\circ} \mathrm{C}$ compared with $37^{\circ} \mathrm{C}$ in PC-12 and Chinese Hamster cells [23]. These adherent cells were however incubated with higher peptide concentrations of between 5 and $10 \mu \mathrm{M}$.

Cholesterol is a major constituent of the mammalian plasma membrane, accounting for between $30-40 \mathrm{~mol} \%$ of the total lipid content [24]. The conformational structure of cholesterol facilitates close interaction with the saturated fatty acid tail of sphingolipids [25], and together with glycosylphosphatidylinositol-anchored proteins, it is found enriched in distinct regions of the plasma membrane called lipid rafts [26]. Cholesterol is fundamental for the function of biological membranes and regulates, amongst other things, plasma membrane fluidity and endocytosis [27]. Cholesterol is required to maintain caveolae structure and for their invagination as caveosomes [28-30], but extraction of plasma membrane cholesterol with methyl- $\beta$-cyclodextrin (M $\beta C D$ ) also affects clathrin mediated uptake and macropinocytosis [31-33]. Cholesterol depletion has previously been reported to inhibit the uptake of Tat peptides in two cell lines [34], however M $\beta C D$ treatment caused an enhanced cytoplasmic labelling of KG1a suspension and adherent $\mathrm{HeLa}$ cells at physiological temperatures using peptide concentrations of 2 and $10 \mu \mathrm{M}$ respectively [16, 17]

We have performed qualitative and quantitative analysis of the cellular uptake and distribution of fluorescently labelled octaarginine in suspension cell lines (KG1a, KG1 K562) and adherent cells (HeLa and A549) at different temperatures and further investigated a role for cholesterol in peptide uptake. Overall the results show that the plasma membrane of 
suspension cells have significantly greater permeability to this peptide at both low and physiological temperatures but this is not due to a peptide-induced increase in cell porosity. We also show that the effects of $M \beta C D$ effects on KG1a cells is specifically due to cholesterol extraction rather than other common effects associated with this agent [35]. 


\section{EXPERIMENTAL}

\section{Reagents}

Alexa Fluor ${ }^{\circledR}$ 488-C5-maleimide and Alexa Fluor ${ }^{\circledR} 488$ Transferrin (Tf) were purchased from Invitrogen (Paisley, U.K). Propidium Iodide (PI), Methyl- $\beta$-cyclodextrin (M $\beta C D)$, Cholesterol and Filipin III were from Sigma-Aldrich (Gillingham, UK). Glass bottomed culture dishes $(35 \mathrm{~mm}$ ) for microscopy were from MatTek Corporation, (Ashland, USA). All tissue culture reagents were from Invitrogen (Paisley, U.K).

\section{Peptide synthesis and conjugation.}

The $R_{L} R_{L} R_{L} R_{L} R_{L} R_{L} R_{L} R_{L} G_{L} C_{L}$ peptide (designated $R_{L} 8$ here) was obtained from American Peptide Company (California, USA) and labelled using Maleimide-C5-Alexa488 sodium salt as previously described [16]. Purification of $\mathrm{R}_{\mathrm{L}} 8$-Alexa488 was by HPLC using a C18 Luna $100 \AA 5 \mu \mathrm{m}$ semi preparative column (Phenomenex, Macclesfield, UK) and its mass (2126.52) was confirmed using electrospray time of flight mass spectroscopy (actual $\mathrm{Mr}=$ 2126.40).

\section{Cell culture}

All cell lines were maintained in a humidified $5 \% \mathrm{CO}_{2}$ incubator at $37^{\circ} \mathrm{C}$. Human acute myeloid leukaemia KG1, KG1a cells, and chronic myeloid leukaemia K562 cells were cultured and maintained at a confluency of $0.5-2 \times 10^{6}$ cells $/ \mathrm{mL}$ in RPMI 1640 medium, supplemented with $10 \%(\mathrm{v} / \mathrm{v})$ foetal calf serum, $100 \mathrm{IU} / \mathrm{mL}$ penicillin and $100 \mu \mathrm{g} / \mathrm{mL}$ streptomycin. Human cervical carcinoma, HeLa, and lung epithelial carcinoma A549 cells were maintained as a subconfluent monolayer in D-MEM supplemented with $10 \%(\mathrm{v} / \mathrm{v})$ foetal calf serum, $100 \mathrm{IU} / \mathrm{mL}$ penicillin and $100 \mu \mathrm{g} / \mathrm{mL}$ streptomycin.

Cellular localisation of $R_{L} 8$-Alexa488 and Alexa488-Tf in suspension and adherent cells. KG1a, KG1 and K562 cells $\left(0.5 \times 10^{6}\right)$ were washed in complete media and equilibrated at 4 or $37^{\circ} \mathrm{C}$ for $15 \mathrm{~min}$. The medium was replaced with fresh temperature equilibrated medium containing 2 or $5 \mu \mathrm{M} \mathrm{R}$ L-Alexa488 or $100 \mathrm{nM}$ Alexa488-Tf and the cells were then incubated with the probes at these temperatures for $1 \mathrm{~h}$. Cells were then washed twice in serum-free RPMI 1640 medium (SFM), once in imaging medium (SFM without Phenol red) and finally resuspended in $500 \mu \mathrm{L}$ of imaging medium. $100 \mu \mathrm{L}$ of the cell suspension was transferred to the centre of glass bottomed $35 \mathrm{~mm}$ culture dishes and the cells were allowed to settle for $30 \mathrm{~s}-1 \mathrm{~min}$. They were then analyzed on a Leica SP5 confocal laser scanning microscope equipped with an $\mathrm{Ar}$ and HeNe laser and a $63 \mathrm{x}$ oil immersion objective.Cells were either imaged through a single section or through the $\mathrm{z}$ axis to generate maximum projection images. Images were finally arranged using Adobe Photoshop.

A549 and HeLa cells $\left(1.8 \times 10^{5}\right)$ were seeded into sterile glass-bottomed, $35 \mathrm{~mm}$ culture dishes and allowed to adhere for $24 \mathrm{hrs}$ under tissue culture conditions. The cells were equilibrated at 4 or $37^{\circ} \mathrm{C}$ for $15 \mathrm{~min}$ prior to replacement of the medium with fresh temperature equilibrated complete medium containing 2,5 or $20 \mu \mathrm{M} \mathrm{R}_{\mathrm{L}} 8$-Alexa488 or 100 $\mathrm{nM}$ Alexa488-Tf. The cells were incubated at these temperatures for $1 \mathrm{~h}$, washed twice in SFM, once in imaging medium and finally resuspended in $500 \mu \mathrm{L}$ of imaging medium for immediate analysis by confocal microscopy as described.

\section{Time lapse microscopy of $R_{L} 8$-Alexa488 uptake in KG1a cells}

Cells $\left(1 \times 10^{5}\right)$ were washed in complete media, resuspended in imaging media containing $10 \% \mathrm{FBS}$ and transferred to $35 \mathrm{~mm}$ imaging dishes that were then placed on a $37^{\circ} \mathrm{C}$ imaging platform on the confocal microscope. $\mathrm{R}_{\mathrm{L}} 8$-Alexa488 was added to final concentrations of 2 or 
$10 \mu \mathrm{M}$ and the cells were allowed to settle for $\sim 30 \mathrm{~s}$, images were then acquired every 30 seconds for $10 \mathrm{~min}$. The bright field and fluorescence frames were then processed as side-byside animations using the Leica LAS AF software.

\section{Flow Cytometry}

Suspension cells $\left(5 \times 10^{5}\right)$ were equilibrated at 4 or $37^{\circ} \mathrm{C}$ for $15 \mathrm{~min}$, prior to incubation for 1 $\mathrm{h}$ with $0-5 \mu \mathrm{M} \mathrm{R}_{\mathrm{L}} 8$-Alexa488 at either 4 or $37^{\circ} \mathrm{C}$. Cells were then washed three times with ice cold phosphate buffered saline (PBS $2.7 \mathrm{mM} \mathrm{KCl}, 137 \mathrm{mM} \mathrm{NaCl}, 10 \mathrm{mM} \mathrm{Na}_{2} \mathrm{HPO}_{4} .2 \mathrm{H}_{2} 0$, $1.8 \mathrm{mM} \mathrm{KK_{2 }} \mathrm{PO}_{4}$ ) and resuspended in $200 \mu \mathrm{L}$ PBS. Cellular fluorescence was then immediately quantified using a Becton Dickinson FACSCalibur analyser as previously described [16]. Live cells were gated on a forward and side scatter basis, and 10,000 viable cells were assayed.

A549 and HeLa cells $\left(0.6 \times 10^{5}\right)$ were seeded into 12 well tissue culture plates and grown to $90 \%$ confluency under tissue culture conditions. The cells were equilibrated at 4 or $37^{\circ} \mathrm{C}$ for $15 \mathrm{~min}$, prior to incubation for $1 \mathrm{~h}$ with $0-5 \mu \mathrm{M} \mathrm{R} \mathrm{R}_{\mathrm{L}} 8$-Alexa488 at either 4 or $37^{\circ} \mathrm{C}$. Cells were washed once with ice cold PBS, incubated with $0.25 \mathrm{mg} / \mathrm{mL}$ trypsin- $0.1 \mathrm{mg} / \mathrm{ml}$ EDTA solution at $37^{\circ} \mathrm{C}$ for $5 \mathrm{~min}$ and then placed as a suspension to $1.5 \mathrm{~mL}$ centrifuge tubes. The cells were washed twice in ice cold PBS and finally resuspended in $200 \mu \mathrm{L}$ ice cold PBS for flow cytometry as described above.

\section{Uptake of $R_{L} 8$-Alexa488 in $M \beta C D$-treated cells}

$\mathrm{KG1a}$ and $\mathrm{K} 562$ cells $\left(5 \times 10^{5}\right)$ were washed once in $37^{\circ} \mathrm{C}$ SFM and incubated for $30 \mathrm{~min}$ at $37^{\circ} \mathrm{C}$ in $200 \mu \mathrm{L}$ SFM containing $5 \mathrm{mM} \mathrm{M} \beta \mathrm{CD}$ from a $100 \mathrm{mM}$ stock in PBS; for control cells M $\beta C D$ was replaced by PBS. Cells were washed in SFM, and incubated for $1 \mathrm{~h}$ with $2 \mu \mathrm{M}$ $\mathrm{R}_{\mathrm{L}} 8$-Alexa488 at $37^{\circ} \mathrm{C}$. The cells were then washed three times in SFM, twice in imaging media and analysed by confocal microscopy or flow cytometry. To assess peptide uptake at $4^{\circ} \mathrm{C}$ following $\mathrm{M} \beta \mathrm{CD}$ treatment, suspension $\mathrm{KG} 1 \mathrm{a}$ cells were treated with $\mathrm{M} \beta \mathrm{CD}$ as above, equilibrated at $4^{\circ} \mathrm{C}$ for 15 min prior to incubation with $2 \mu \mathrm{M} \mathrm{R} \mathrm{R}_{\mathrm{L}} 8$-Alexa488 at $4^{\circ} \mathrm{C}$, and analysed as above.

A549 and HeLa cells $\left(1.8 \times 10^{5}\right)$ seeded into $35 \mathrm{~mm}$ imaging dishes were washed once in $\operatorname{SFM}\left(37^{\circ} \mathrm{C}\right)$, and incubated for $30 \mathrm{~min}$ at $37^{\circ} \mathrm{C}$ in $750 \mu \mathrm{L}$ SFM containing $5 \mathrm{mM} \mathrm{M} \beta C D$. The cells were then incubated with the peptide, washed, trypsinised and processed for flow cytometry as described above.

\section{Preparation of $5 \mathrm{mMM} \beta \mathrm{MCD}$ complexed with cholesterol (M $\beta C D$ :Chol)}

A $5 \mathrm{mM}$ solution of $\mathrm{M} \beta \mathrm{CD}$ saturated with cholesterol (M $\beta C D$ :Chol) was prepared using an adaptation of a previously described method [36]. Briefly, $16 \mu \mathrm{L}$ of cholesterol from a stock solution $(50 \mathrm{mg} / \mathrm{mL}$ in chloroform:methanol (1:1)) was added to a $50 \mathrm{~mL}$ glass flask. The solvent was evaporated under nitrogen, and $20 \mathrm{~mL}$ of SFM containing $132 \mathrm{mg}$ of M $\beta C D$ was added. The flask was sealed, sonicated in a bath sonicator for $3 \mathrm{~min}$ and finally incubated overnight at $37^{\circ} \mathrm{C}$ with rotation. The $\mathrm{M} \beta \mathrm{CD}$ :Chol solution was finally filtered through a 0.45 $\mu \mathrm{m}$ syringe filter into a $50 \mathrm{~mL}$ conical flask and stored for up to 7 days $4^{\circ} \mathrm{C}$.

\section{Replenishment of cellular cholesterol with $\mathrm{M} \beta \mathrm{CD}$ :Chol}

KGla cells $\left(0.5 \times 10^{6}\right)$ were washed in $37^{\circ} \mathrm{C}$ equilibrated SFM, centrifuged and media was replaced with either media containing $5 \mathrm{mM} \mathrm{M} \beta C D$ or M $\beta C D$ :Chol (Table 1-INSERT TABLE 1 HERE). After $30 \mathrm{~min}$ at $37^{\circ} \mathrm{C}$ the cells were washed with SFM and incubated for 
$30 \mathrm{~min}$ at $37^{\circ} \mathrm{C}$ in either SFM or M $\beta C D$ :Chol (Table 1). Cells were finally washed in SFM and equilibrated on ice for $15 \mathrm{~min}$ prior to a $1 \mathrm{~h}$ incubation in ice cold complete medium containing $2 \mu \mathrm{M} \mathrm{R} \mathrm{R}_{\mathrm{L}} 8$-Alexa488. Cells were washed three times in ice-cold PBS and immediately analysed for $\mathrm{R}_{\mathrm{L}} 8$-Alexa488 uptake by flow cytometry as previously described.

\section{Filipin staining}

KG1a cells $\left(0.5 \times 10^{6}\right)$ were treated as described in Table 1 but rather than adding peptide they were stained with Filipin III using a previously described method [37]. Briefly, cells were washed three times in PBS and then fixed with 3\% w/v paraformaldehyde in PBS for 30 min at room temperature. The cells were washed three times in PBS, resuspended in $120 \mu \mathrm{L}$ PBS and $30 \mu 1$ aliquots were placed on multiwell microscope slides (Hendley, Essex, UK). The cells were allowed to settle for approximately $30 \mathrm{~s}$ before removing $25 \mu \mathrm{l}$ of the surface liquid. The remaining cells were then dried for $3 \mathrm{~min}$ and the paraformaldehyde was quenched for $15 \mathrm{~min}$ with $50 \mathrm{mM}$ glycine/PBS. The microscope slides were immersed three times in PBS prior to addition of $50 \mu \mathrm{g} / \mathrm{ml}$ Filipin III in PBS. The cells were incubated with this agent for $2 \mathrm{~h}$ at room temperature prior to another round of washing in PBS. The wells were covered with a coverslip, sealed with nail varnish and imaged through the UV $(350 \mathrm{~nm})$ channel of a Leica DMIRB inverted fluorescence microscope equipped with a $40 \mathrm{x}$ oilimmersion objective. Images were captured on a Qimaging Retiga 1300 camera and Filipin fluorescence of individual cells was quantified using Image J software. Each experiment was performed three times and a total of 300 cells were analysed for each experiment thus the data represents analysis from 900 cells.

\section{Cell permeability studies}

$\mathrm{KGla}, \mathrm{KG1}$ and $\mathrm{K} 562$ cells $\left(0.5 \times 10^{6}\right)$ were equilibrated at $4^{\circ} \mathrm{C}$ for $15 \mathrm{~min}$, washed in complete media and incubated for $1 \mathrm{~h}$ in complete media containing 2 or $5 \mu \mathrm{M} \mathrm{R}_{\mathrm{L}} 8$ and 5 $\mu \mathrm{g} / \mathrm{mL}$ PI. The cells were washed three times in ice cold PBS, resuspended in $200 \mu \mathrm{L}$ PBS and analysed by flow cytometry. For $\mathrm{M} \beta \mathrm{CD}$ treated cells, KG1a and K562 cells were preincubated with $5 \mathrm{mM} \mathrm{M \beta CD}$ for $30 \mathrm{~min}$, washed in SFM and incubated as above with 2 $\mu \mathrm{M} \mathrm{R}_{\mathrm{L}} 8$ and PI prior to analysis by flow cytometry. For cholesterol depletion and addition experiments, KG1a cells were treated as described in Table 1, washed in complete media and co-incubated for $1 \mathrm{~h}$ in complete media containing $2 \mu \mathrm{M} \mathrm{R} \mathrm{R}_{\mathrm{L}} 8$ and PI at $4{ }^{\circ} \mathrm{C}$. The cells were washed three times in ice cold PBS and resuspended in $200 \mu \mathrm{L}$ PBS prior to analysis by flow cytometry.

A549 and HeLa cells were seeded into 12 well plates at a density of $0.6 \times 10^{5}$ cells per well and grown to confluency under tissue culture conditions. Cells were incubated in the absence or presence of $5 \mathrm{mM} \mathrm{M \beta CD}$ for $30 \mathrm{~min}$, washed once in SFM and incubated with $2 \mu \mathrm{M} \mathrm{R} \mathrm{R}_{\mathrm{L}} 8$ and PI. Cells were washed once with ice cold PBS, incubated with trypsin/EDTA solution at $37^{\circ} \mathrm{C}$ for $5 \mathrm{~min}$ and then placed as a suspension into $1.5 \mathrm{~mL}$ centrifuge tubes. The cells were washed twice in ice cold PBS and finally resuspended in $200 \mu \mathrm{L}$ ice cold PBS for flow cytometry. 


\section{RESULTS}

Our previous work showed that the cellular localisation of $\mathrm{R}_{\mathrm{L}} 8$-Alexa488 peptide in $\mathrm{CD} 34^{+}$ $\mathrm{KG} 1 \mathrm{a}$ leukaemia cells at $\leq 2 \mu \mathrm{M}$ altered from being vesicular at $37^{\circ} \mathrm{C}$ to diffuse-cytoplasmic at $4^{\circ} \mathrm{C}$ [16]. However, a similar diffuse distribution of peptide was observed in these cells following $37^{\circ} \mathrm{C}$ incubations when the extracellular peptide concentration was increased or when plasma membrane cholesterol was sequestered. We therefore investigated whether these effects could be observed in other suspension cells and adherent cell lines. For suspension cells we used the previously reported KG1a and K562 lines [16, 21] and also utilised KG1 cells that are a more differentiated subpopulation of the original KG1a line [38]. Near identical experiments we also performed in adherent HeLa and A549 cells.

We initially incubated all the leukemic cell lines for $1 \mathrm{~h}$ with either 2 or $5 \mu \mathrm{M}$ peptide at 37 or $4^{\circ} \mathrm{C}$ and assessed peptide distribution using confocal microscopy. Alexa488-Tf was also utilised for these studies as this is a well characterised endocytic marker. As shown in Figure 1, a vesicular pattern of labelling was seen in all cell lines incubated at $37^{\circ} \mathrm{C}$ with $2 \mu \mathrm{M} \mathrm{R} \mathrm{R}_{\mathrm{L}} 8$ Alexa488. As previously shown, KG1a cells displayed fluorescent vesicles distributed throughout the cytoplasm, while the K562 cells showed labelling clustered within the perinuclear region of the cells [39]; KG1 cells showed a vesicular pattern of labelling similar to that of KGla. When the peptide concentration was increased to $5 \mu \mathrm{M}$ there was evidence of diffuse cytosolic labelling in the three suspension cell lines and this was accompanied by punctate fluorescence (Figure 1). Decreasing the incubation temperature to $4^{\circ} \mathrm{C}$ resulted in diffuse cytoplasmic labelling in all three cell lines when the external concentration was 2 or 5 $\mu \mathrm{M}$. The localisation of $\mathrm{Tf}$ was similar to that of the peptide at $37^{\circ} \mathrm{C}$ but was confined, in all three cell lines, to the plasma membrane following $4^{\circ} \mathrm{C}$ incubations. Images in Figure 1 are maximum projection images from multiple sections and single images through the middle of the same cells are shown in Supplementary Figure 1.

In HeLa cells, two independent studies have shown that strong cytoplasmic labelling of R912 emanates as a wave of peptide from a distinct region of the plasma membrane $[17,18]$. We therefore incubated KG1a cells with either 2 or $10 \mu \mathrm{M}$ of $\mathrm{R}_{\mathrm{L}} 8$-Alexa488 and performed time-lapse confocal microscopy every 30 seconds for $10 \mathrm{~min}$ in the continued presence of the peptide. Shown in Figure 2 are individual frames showing bright field or $488 \mathrm{~nm}$ fluorescence profiles immediately following peptide addition (0) and then after 5 and 10 min; movies spanning the entire $10 \mathrm{~min}$ experiment are shown as Supplementary videos $1-4$. At 2 $\mu \mathrm{M}$ peptide concentration there was little evidence of vesicular labelling throughout the experiment but at $10 \mu \mathrm{M}$ peptide concentrations, there was very strong diffuse fluorescence in a number of cells within 3 min and after 10 minutes the majority of cells had quantities of intracellular fluorescence equivalent to the background and were then only visible through the bright-field view (Figure 2B and Supplementary videos 3-4). Some cells however were more resistant to this effect and a small fraction was almost devoid of fluorescence even after $10 \mathrm{~min}$. We also performed the same peptide experiments in the presence of propidium iodide (PI) but the peptide showed no evidence of enhancing the uptake of this probe (data not shown). Similar results were obtained when identical experiments were performed in K562 cells (data not shown)

To also exclude the possibility that the distribution of $\mathrm{R}_{\mathrm{L}} 8$-Alexa488 seen at $4^{\circ} \mathrm{C}$ in Figure 1 was a consequence of a general increase in plasma membrane permeability, we co-incubated, on ice, all the suspension cells with 2 or $5 \mu \mathrm{M} \mathrm{R} \mathrm{R}_{\mathrm{L}} 8$ and PI and then quantified PI uptake by flow cytometry. Less than $3 \%$ of untreated cells were PI positive and $\mathrm{R}_{\mathrm{L}} 8$ had no significant effect in any of the three cells lines on the uptake of this probe. 
Several of these experiments were then performed in adherent cell lines. HeLa and A549 cells displayed vesicular labelling at both 2 and $5 \mu \mathrm{M}$ peptide concentration when experiments were performed at $37^{\circ} \mathrm{C}$ (Figure 3 ). When identical experiments were performed on ice, only plasma membrane labelling was observed in A549 cells but some evidence of cytoplasmic labelling was observed in $\mathrm{HeLa}$ cells at $5 \mu \mathrm{M}$ (Figure $3 \mathrm{~A}$ ). We therefore incubated both cell lines with $20 \mu \mathrm{M}$ peptide at 4 and $37^{\circ} \mathrm{C}$ (Figure $3 \mathrm{~B}$ ). At $37^{\circ} \mathrm{C}$ some HeLa cells displayed evidence of diffuse as well as vesicular labelling, however, no diffuse cytosolic labelling was observed in A549 cells. When cells were incubated at this increased peptide concentration on ice there was strong diffuse cytosolic labelling in HeLa cells but approximately $40 \%$ of the A549 cells had no evidence of cytosolic labelling and in these cells the peptide was localised, primarily to the plasma membrane (Figure 3B). Again the maximum projection images are shown and single section images shown in Supplementary Figure 2 show more distinct plasma membrane labelling.

\section{Quantification of $R_{\mathrm{L}} 8$-Alexa488 uptake at 4 and $37^{\circ} \mathrm{C}$}

We then quantified the amount of peptide internalised at 4 and $37^{\circ} \mathrm{C}$, initially in the suspension cell lines. At all studied concentrations, the K562 cell line internalised significantly higher $(\sim 2.5$ fold $)$ amounts of the peptide compared with KG1 and KG1a cells at $37^{\circ} \mathrm{C}$, however, at $4^{\circ} \mathrm{C}$ fluorescence was significantly higher $(\sim 2.0$ fold $)$ in KG1 and KG1a cell lines (Figure 4A). Analysis of cellular fluorescence profiles of the leukaemia cells following $4^{\circ} \mathrm{C}$ incubations show that all the cell lines exhibit two distinct populations, one of high fluorescence and one of low fluorescence (Figure 5A-B); this was previously noted in KGla cells [16].

These experiments were then performed in adherent cell lines and HeLa cells accumulated significantly higher amounts of $\mathrm{R}_{\mathrm{L}} 8$-Alexa488 compared with $\mathrm{A} 549$ cells, and suspension cells (Figure $4 \mathrm{~A}, \mathrm{C}$ ). However, at $4^{\circ} \mathrm{C}$, peptide accumulation was much lower in both adherent cell lines compared with the suspension cells (Figure 4D). Cellular FACS profiles from representative experiments are shown in Figure $5 \mathrm{C}-\mathrm{D}$. Under all conditions only one major peak of fluorescence was observed but increasing the peptide concentration increased the range of fluorescence intensities in both cell lines and thus a broadening of the peaks.

\section{Effects of Cholesterol depletion on the uptake of $\mathbf{R}_{\mathrm{L}} 8$-Alexa488 at $37^{\circ} \mathrm{C}$}

Our previous work showed that pre-incubating KGla cells with $\mathrm{M} \beta C D$ resulted in an influx of $2 \mu \mathrm{M} \mathrm{R} \mathrm{R}_{\mathrm{L}} 8$-Alexa488 into the cytosol when peptide incubations were performed at $37^{\circ} \mathrm{C}$ [16]. We extended these studies to include K562, HeLa and A549 cells and for this the cells were pre-incubated with $5 \mathrm{mM} \mathrm{M} \beta C D$ before washing and adding $\mathrm{R}_{\mathrm{L}} 8$-Alexa488 at $2 \mu \mathrm{M}$ for $1 \mathrm{~h}$ at $37^{\circ} \mathrm{C}$. Figure $6 \mathrm{~A}$ shows that $\mathrm{M} \beta \mathrm{CD}$ treated $\mathrm{KG1}$ a cells exhibit a predominantly diffuse cytoplasmic labelling but peptide labelled vesicles were also observed. Similar though less pronounced effects were observed in K562 cells and the prominent perinuclear region labelling was also clearly in evidence. This enhanced diffuse labelling was not extended to the adherent A549 and HeLa cells, as M $\beta C D$ treated cells display $\mathrm{R}_{\mathrm{L}} 8$-Alexa488 localised to distinct intracellular vesicles. The likelihood that the cytosolic labelling of $\mathrm{R}_{\mathrm{L}} 8$-Alexa488 observed in KG1a and K562 following M $\beta$ CD mediated cholesterol sequestration was due to increased permeability was again ruled out using PI co-incubation experiments. M $\beta C D$ treatment had no effect on the number of PI positive cells which remained at $<2 \%$ of the total. 
To quantify the effects of $M \beta C D$ on peptide uptake, the cells were treated with $5 \mathrm{mM} \mathrm{M} \beta C D$ as above prior to measuring cellular fluorescence using flow cytometry. M $\beta C D$ treatment of $\mathrm{KG1a}$ and $\mathrm{K} 562$ resulted in a significant reduction in the average cell fluorescence; $36 \%(\mathrm{P}=$ $<0.01)$ in KG1a and 58\% (P < 0.01) in K562 cells. M 3 CD treated HeLa cells showed a 20\% decrease of cell associated fluorescence whilst A549 cells showed a 5\% increase in cell fluorescence (Figure 6B), however, neither of these were significantly different from control cells.

As HeLa and A549 cells still exhibited vesicular labelling of both $\mathrm{R}_{\mathrm{L}} 8$-Alexa488 and $\mathrm{Tf}$ following $5 \mathrm{mM} \mathrm{M} \beta C D$ treatment, the concentration of $\mathrm{M} \beta C D$ was increased to $10 \mathrm{mM}$ and the cells were pre-incubated with this compound for 30 or $60 \mathrm{~min}$ prior to the addition of peptide. Some HeLa cells displayed weak diffuse fluorescence, however, $\mathrm{R}_{\mathrm{L}} 8$-Alexa488 containing vesicles were also clearly visible. Under the same experimental conditions the peptide in the A549 cells was still localised to distinct vesicles. These vesicles appeared to be larger in size and much fewer in number than those seen in untreated cells, and the degree of plasma membrane labelling was also more prominent (Supplementary Figure 3). Increasing the $\mathrm{M} \beta C D$ pre-incubation time to $60 \mathrm{~min}$ enhanced the degree of diffuse cytoplasmic labelling but transferrin in these cells was largely contained on the plasma membrane. Cellular morphology was also significantly altered, and cells tended to lift from the tissue culture plastic during the experiments. The A549 cells were much more resilient and under these harsh conditions and continued to display peptide and transferrin labelled vesicles (Supplementary Figure 3).

\section{Effects of Cholesterol depletion on the uptake of $R_{L} 8$-Alexa488 at $4{ }^{\circ} \mathrm{C}$}

This study and our previous work has highlighted the effects of $M \beta C D$ on the uptake of $R_{L} 8$ Alexa488 at $37^{\circ} \mathrm{C}$ in KG1a cells [16] and we investigated whether similar effects were observed when $\mathrm{M} \beta C D$ treated cells were treated with the peptide on ice. KG1a cells were pre-incubated in $5 \mathrm{mM} \mathrm{M} \beta C D$ and incubated on ice with $2 \mu \mathrm{M} \mathrm{R}_{\mathrm{L}} 8$-Alexa488. Figure 7 shows that $\mathrm{M} \beta \mathrm{CD}$ treatment results in a significant increase $(\mathrm{P}=<0.01)$ in the proportion of cells in the high fluorescence peak; $56 \%$ in control cells versus $86 \%$ in $\mathrm{M} \beta \mathrm{CD}$ treated cells. The fluorescence of the high peak in $\mathrm{M} \beta \mathrm{CD}$ treated cells was also significantly higher than control cells $(\mathrm{P}=<0.01)$. Thus, in KGla cells, $\mathrm{M} \beta \mathrm{CD}$ decreased and increased cellular accumulation of the peptide at 37 and $4{ }^{\circ} \mathrm{C}$ respectively. Common to both conditions was the accompanying prominence of diffuse cytoplasmic labelling.

\section{Addition and replenishment of cholesterol using $M \beta C D$ cholesterol complexes (MßCD:Chol)}

Complexes were prepared as described in the methods and added to either control cells or cells previously depleted of cholesterol (Table 1); they were then incubated with the peptide on ice. As previously shown in Figure 7, M $\beta C D$ treatment of control cells led to the loss of the low peak as $87 \%$ of the cell population now accumulated a much higher quantity of the peptide. Addition of the $\mathrm{M} \beta \mathrm{CD}$ :Chol complex to cholesterol depleted cells, however, restored the peak profiles to those of control cells (Figure 8C); similar profiles were also observed when untreated cells were incubated with the complexes prior to peptide addition (Figure 8D). Cholesterol addition to either untreated (Figure 8D) or cholesterol depleted cells (Figure 8C) consistently increased the number of cells falling within the low peak, however this effect was not statistically significant. Identical experiments with PI showed that none of these treatments increased cellular permeability and $98 \%$ of the cells were negative for PI. 
The polyene antibiotic Filipin III binds cholesterol and may be used, in conjunction with fluorescence microscopy, to visualise cellular cholesterol. We therefore analysed Fillipin staining intensity and distribution in cells treated as above (Table 1). The cells were fixed and incubated with Filipin at the point in the experiment where the peptide would normally have been added. The right hand columns in Figure 8 show representative images of Filipin labelling in cells and comparison of control and M $\beta C D$ treated cells in Figures $8 \mathrm{~A}$ and $\mathrm{B}$ highlight the ability of this agent to extract cholesterol. The intensity of staining in Fig $8 \mathrm{C}$ was appreciably higher than that in Figure $8 \mathrm{~B}$ suggesting that some cholesterol replenishment had occurred in cells that were previously treated with $M \beta C D$ and then incubated with M $\beta C D$ :Cholesterol complexes (Figure 8C). Figure 8D confirms the effectiveness of M $\beta C D$ as a cholesterol donor as control cells incubated with complexes had increased fillipin staining. We quantified the fluorescence of 900 individual cells for each condition and Figure $8 \mathrm{E}$ confirms the microscopy data and show that $\mathrm{M} \beta \mathrm{CD}$ :cholesterol complexes increased the fluorescence of control cells by $\sim 40 \%$ and addition of the complexes to cholesterol depleted cells restored cholesterol levels to control levels. 


\section{DISCUSSION}

Recent studies from independent laboratories show that increasing the concentrations of cationic CPPs above a certain threshold leads to a dramatic increase in the fraction that is diffusely localised in the cytoplasm [16, 17, 20]. Time lapse imaging experiments at high peptide concentration in HeLa cells shows that an aggregation of peptide in a distinct region of the plasma membrane acts as a nucleation zone for subsequent spreading to other cellular locations $[17,18]$. This process was inhibited by the protein kinase $\mathrm{C} \delta$ inhibitor rotterlin, and the endocytic inhibitor chlorpromazine, suggesting it is an active process [17]. We did not observe these nucleated regions in leukaemia cells when similar time-lapse microscopy experiments were performed during addition of the peptide and thereafter in its continued presence. This suggests that the noted peptide aggregation at the plasma membrane, preceding translocation, is not a common entry mechanism. We also show extensive diffuse cytoplasmic labelling in suspension and adherent cell lines when peptide incubations were performed on ice. The concentration required to visualise this effect was much higher in adherent cells compared with the leukaemia cells but overall the data argues that in these experiments, peptide translocation across the plasma membrane is an energy independent process. In line with this, flow cytometry analysis showed that accumulation of the peptide following incubations on ice at $2 \mu \mathrm{M}$ was 10 or 20 fold higher in K562 and KG1/KG1a cells respectively compared with adherent cells. Studies in Jurkat cells, another suspension cell line, using relatively high peptide concentrations of $12.5-25 \mu \mathrm{M}$ showed pronounced cytosolic labelling of R7-R9 at room temperature and $3^{\circ} \mathrm{C}$ incubations [40, 41].

When KG1a cells were incubated at $37^{\circ} \mathrm{C}$ for $10 \mathrm{~min}$ with the peptide at $2 \mu \mathrm{M}$ we were unable to observe any significant vesicular labelling and longer incubations are required for these to be clearly seen. This is consistent with a requirement, under these conditions, for time and endocytosis for uptake to be visualised. However we cannot refute the possibility that even at these low concentrations, an undetected fraction of peptide gains access to the cells directly across the plasma membrane. Increasing the peptide concentration to $10 \mu \mathrm{M}$ in KG1a cells resulted in a very rapid cytosolic accumulation with no evidence of a requirement for endocytosis or indeed any energy dependent process. At intermediate concentrations $(2-$ $10 \mu \mathrm{M})$ it is difficult to ascertain how much of the peptide actually enters KG1a cells via endocytosis or directly through the plasma membrane and, in view of these studies and other recent publications $[17,18,20]$, the same could be said for other cell types.

Though all cell lines studied here have a capacity to allow peptide entry directly through the plasma membrane at $4{ }^{\circ} \mathrm{C}$ the adherent cells are much more refractory to this. The reason for this is currently unknown but the peptide did not induce leakage of PI in any of the studied cell lines. As endocytosis is an energy-dependent process, lowering the temperature of peptide incubations to $4^{\circ} \mathrm{C}$ should effectively eliminate the involvement of endocytosis in internalisation, thus direct permeation of peptide through the plasma membrane is responsible for the observed results. All of these cell lines will have unique plasma membrane compositions in terms of lipids, proteins and carbohydrates and these may influence membrane porosity to R8 and other CPPs. A549 cells were the most resistant to peptide entry under all conditions and these are models for alveolar type II pneumocytes, the cells responsible for the production and secretion of pulmonary surfactant in vivo [42-44]. In culture they have been shown to secrete high levels of di-saturated phosphatidylcholine [43] and this could influence the effective peptide concentration, peptide interaction with the plasma membrane and thus translocation across this structure. Quantitative uptake experiments with suspension cells were performed without trypsinisation and heparin 
washing but this treatment has very little effect on fluorescence values in these cells lines [16]. The fraction of peptide that is located on the plasma membrane is higher in the adherent cells that we have studied, and analysis of these requires these additional treatments.

Diffuse cytoplasmic peptide distribution was observed in all cell lines following cholesterol depletion; but higher $\mathrm{M} \beta \mathrm{CD}$ concentrations and incubation times were required to observe these effects in adherent lines, especially A549 cells. The amount of cholesterol sequestered by this agent is cell line, and incubation time dependant [35] and this may explain the differences in experimental conditions required to induce diffuse labelling. We did not observe a general increase in cell porosity with $5 \mathrm{mM} \mathrm{M} \beta \mathrm{CD}$, but higher concentrations of and longer incubations had very obvious effects on cell morphology. Despite inducing a diffuse peptide labelling, $\mathrm{M} \beta \mathrm{CD}$ caused an overall reduction in peptide uptake in suspension cells but was without effect in HeLa and A549 cells. This is in agreement with earlier studies showing $\mathrm{M} \beta \mathrm{CD}$ to have no effect on R9 and Tat uptake in HeLa cells, provided the peptide concentration was $<5 \mu \mathrm{M}$ [17]. At higher peptide concentrations, cholesterol depletion promoted the rapid translocation of these two CPPs through the plasma membrane. Though experiments performed with MßCD give interesting data, the fact that it causes this peptide and other CPPs to change their entry mechanisms, cautions against its use as a sole method for assessing the role of lipid rafts and other membrane domains in CPP uptake.

Preparation of the MßCD:Chol complexes allowed us for the first time to investigate whether addition of cholesterol to either control or cholesterol depleted cells had any effects on peptide uptake. These kinds of experiments are often performed to confirm that the effects of MßCD are solely due to cholesterol depletion from the plasma membrane [35]. Flow cytometry and microscopy of KGla and other suspension cells following peptide incubation on ice reveal a distinct and significant population of cells that have very low levels of internalised peptide. These, based on the flow cytometry profiles, were termed the low peak population [16]. Adding additional cholesterol to these cells had little effect on the fluorescence profiles but the overall increase in cholesterol values was small and may not have been sufficient to cause an effect. Cholesterol depletion however, resulted in the disappearance of this population and all the cells internalised higher amounts of peptide. Cells in this low peak population may therefore have higher plasma membrane cholesterol levels and the peptide is therefore less able to gain access to the cell interior. In support of this is the fact that we could reverse the effects of MBCD treatment by adding cholesterol thus demonstrating the critical role of this steroid in CPP translocation under these conditions.

These studies have shed further light on cellular and experimental parameters that influence the uptake, through the plasma membrane or endocytic pathways, and intracellular distribution of cationic CPPs in different cell lines. This could help in the design of new CPPstrategies for the cellular delivery of therapeutic macromolecules; a major goal for this field of research. 


\section{FUNDING}

This work was supported by BBSRC Grant BB/D013038 to A.T. Jones and Grants-in-Aid for Scientific Research, Ministry of Education, Culture, Sports, Science and Technology of Japan to S. Futaki. 


\section{REFERENCES}

1 Frankel, A. and Pabo, C. (1988) Cellular uptake of the tat protein from human immunodeficiency virus. Cell. 55, 1189-1193

2 Green, M. and Loewenstein, P. (1988) Autonomous functional domains of chemically synthesized human immunodeficiency virus tat trans-activator protein. Cell. 55, 1179-1188

3 Fischer, R., Fotin-Mleczek, M., Hufnagel, H. and Brock, R. (2005) Break on through to the other side-biophysics and cell biology shed light on cell-penetrating peptides. Chembiochem. 6, 2126-2142

4 Nakase, I., Takeuchi, T., Tanaka, G. and Futaki, S. (2008) Methodological and cellular aspects that govern the internalization mechanisms of arginine-rich cell-penetrating peptides. Advanced Drug Delivery Reviews. 60, 598-607

5 Meade, B. and Dowdy, S. (2007) Exogenous siRNA delivery using peptide transduction domains/cell penetrating peptides. Adv Drug Deliv Rev. 59, 134-140

6 Dietz, G. and Bähr, M. (2004) Delivery of bioactive molecules into the cell: the Trojan horse approach. Mol Cell Neurosci. 27, 85-131

$7 \quad$ Koppelhus, U. and Nielsen, P. (2003) Cellular delivery of peptide nucleic acid (PNA). Adv Drug Deliv Rev. 55, 267-280

8 Derossi, D., Calvet, S., Trembleau, A., Brunissen, A., Chassaing, G. and Prochiantz, A. (1996) Cell internalization of the third helix of the Antennapedia homeodomain is receptor-independent. J Biol Chem. 271, 18188-18193

9 Vivès, E., Brodin, P. and Lebleu, B. (1997) A truncated HIV-1 Tat protein basic domain rapidly translocates through the plasma membrane and accumulates in the cell nucleus. J Biol Chem. 272, 16010-16017

10 Lundberg, M. and Johansson, M. (2002) Positively charged DNA-binding proteins cause apparent cell membrane translocation. Biochem Biophys Res Commun. 291, 367-371

11 Richard, J., Melikov, K., Vives, E., Ramos, C., Verbeure, B., Gait, M., Chernomordik, L. and Lebleu, B. (2003) Cell-penetrating peptides. A reevaluation of the mechanism of cellular uptake. J Biol Chem. 278, 585-590

12 Fittipaldi, A., Ferrari, A., Zoppé, M., Arcangeli, C., Pellegrini, V., Beltram, F. and Giacca, M. (2003) Cell membrane lipid rafts mediate caveolar endocytosis of HIV-1 Tat fusion proteins. J Biol Chem. 278, 34141-34149

13 Kaplan, I., Wadia, J. and Dowdy, S. (2005) Cationic TAT peptide transduction domain enters cells by macropinocytosis. J Control Release. 102, 247-253

14 Fuchs, S. and Raines, R. (2004) Pathway for polyarginine entry into mammalian cells. Biochemistry. 43, 2438-2444

15 Ferrari, A., Pellegrini, V., Arcangeli, C., Fittipaldi, A., Giacca, M. and Beltram, F. (2003) Caveolae-mediated internalization of extracellular HIV-1 tat fusion proteins visualized in real time. Mol Ther. 8, 284-294

16 Fretz, M., Penning, N., Al-Taei, S., Futaki, S., Takeuchi, T., Nakase, I., Storm, G. and Jones, A. (2007) Temperature-, concentration- and cholesterol-dependent translocation of Land D-octa-arginine across the plasma and nuclear membrane of CD34+ leukaemia cells. Biochem J. 403, 335-342

17 Duchardt, F., Fotin-Mleczek, M., Schwarz, H., Fischer, R. and Brock, R. (2007) A comprehensive model for the cellular uptake of cationic cell-penetrating peptides. Traffic. 8 , 848-866

18 Kosuge, M., Takeuchi, T., Nakase, I., Jones, A. and Futaki, S. (2008) Cellular internalization and distribution of arginine-rich peptides as a function of extracellular peptide concentration, serum, and plasma membrane associated proteoglycans. Bioconjug Chem. 19, 656-664 
19 Jones, A. (2007) Macropinocytosis: searching for an endocytic identity and role in the uptake of cell penetrating peptides. J Cell Mol Med. 11, 670-684

20 Tünnemann, G., Ter-Avetisyan, G., Martin, R., Stöckl, M., Herrmann, A. and Cardoso, M. (2008) Live-cell analysis of cell penetration ability and toxicity of oligoarginines. J Pept Sci. 14, 469-476

21 Al-Taei, S., Penning, N., Simpson, J., Futaki, S., Takeuchi, T., Nakase, I. and Jones, A. (2006) Intracellular traffic and fate of protein transduction domains HIV-1 TAT peptide and octaarginine. Implications for their utilization as drug delivery vectors. Bioconjug Chem. 17, 90-100

22 Nakase, I., Niwa, M., Takeuchi, T., Sonomura, K., Kawabata, N., Koike, Y., Takehashi, M., Tanaka, S., Ueda, K., Simpson, J., Jones, A., Sugiura, Y. and Futaki, S. (2004) Cellular uptake of arginine-rich peptides: roles for macropinocytosis and actin rearrangement. Mol Ther. 10, 1011-1022

23 Thorén, P., Persson, D., Isakson, P., Goksör, M., Onfelt, A. and Nordén, B. (2003) Uptake of analogs of penetratin, Tat(48-60) and oligoarginine in live cells. Biochem Biophys Res Commun. 307, 100-107

24 Lange, Y., Swaisgood, M., Ramos, B. and Steck, T. (1989) Plasma membranes contain half the phospholipid and $90 \%$ of the cholesterol and sphingomyelin in cultured human fibroblasts. J Biol Chem. 264, 3786-3793

25 Brown, D. and London, E. (1998) Structure and origin of ordered lipid domains in biological membranes. J Membr Biol. 164, 103-114

26 Munro, S. (2003) Lipid rafts: elusive or illusive? Cell. 115, 377-388

27 Brown, D. and London, E. (2000) Structure and function of sphingolipid- and cholesterol-rich membrane rafts. J Biol Chem. 275, 17221-17224

28 Murata, M., Peränen, J., Schreiner, R., Wieland, F., Kurzchalia, T. and Simons, K. (1995) VIP21/caveolin is a cholesterol-binding protein. Proc Natl Acad Sci U S A. 92, 10339-10343

29 Rothberg, K., Ying, Y., Kamen, B. and Anderson, R. (1990) Cholesterol controls the clustering of the glycophospholipid-anchored membrane receptor for 5methyltetrahydrofolate. J Cell Biol. 111, 2931-2938

30 Hailstones, D., Sleer, L., Parton, R. and Stanley, K. (1998) Regulation of caveolin and caveolae by cholesterol in MDCK cells. J Lipid Res. 39, 369-379

31 Rodal, S., Skretting, G., Garred, O., Vilhardt, F., van Deurs, B. and Sandvig, K. (1999) Extraction of cholesterol with methyl-beta-cyclodextrin perturbs formation of clathrin-coated endocytic vesicles. Mol Biol Cell. 10, 961-974

32 Subtil, A., Gaidarov, I., Kobylarz, K., Lampson, M., Keen, J. and McGraw, T. (1999) Acute cholesterol depletion inhibits clathrin-coated pit budding. Proc Natl Acad Sci U S A. 96, 6775-6780

33 Grimmer, S., van Deurs, B. and Sandvig, K. (2002) Membrane ruffling and macropinocytosis in A431 cells require cholesterol. J Cell Sci. 115, 2953-2962

34 Wadia, J., Stan, R. and Dowdy, S. (2004) Transducible TAT-HA fusogenic peptide enhances escape of TAT-fusion proteins after lipid raft macropinocytosis. Nat Med. 10, 310315

35 Zidovetzki, R. and Levitan, I. (2007) Use of cyclodextrins to manipulate plasma membrane cholesterol content: evidence, misconceptions and control strategies. Biochim Biophys Acta. 1768, 1311-1324

36 Christian, A., Haynes, M., Phillips, M. and Rothblat, G. (1997) Use of cyclodextrins for manipulating cellular cholesterol content. J Lipid Res. 38, 2264-2272 
37 Mukherjee, S., Zha, X., Tabas, I. and Maxfield, F. (1998) Cholesterol distribution in living cells: fluorescence imaging using dehydroergosterol as a fluorescent cholesterol analog. Biophys J. 75, 1915-1925

38 Koeffler, H., Billing, R., Lusis, A., Sparkes, R. and Golde, D. (1980) An undifferentiated variant derived from the human acute myelogenous leukemia cell line (KG1). Blood. 56, 265-273

39 Jin, J., Pastrello, D., Penning, N. and Jones, A. (2008) Clustering of endocytic organelles in parental and drug-resistant myeloid leukaemia cell lines lacking centrosomally organised microtubule arrays. Int J Biochem Cell Biol. 40, 2240-2252

40 Mitchell, D., Kim, D., Steinman, L., Fathman, C. and Rothbard, J. (2000) Polyarginine enters cells more efficiently than other polycationic homopolymers. J Pept Res. 56, 318-325

41 Wender, P., Mitchell, D., Pattabiraman, K., Pelkey, E., Steinman, L. and Rothbard, J. (2000) The design, synthesis, and evaluation of molecules that enable or enhance cellular uptake: peptoid molecular transporters. Proc Natl Acad Sci U S A. 97, 13003-13008

42 Smith, B. (1977) Cell line A549: a model system for the study of alveolar type II cell function. Am Rev Respir Dis. 115, 285-293

43 Shapiro, D., Nardone, L., Rooney, S., Motoyama, E. and Munoz, J. (1978) Phospholipid biosynthesis and secretion by a cell line (A549) which resembles type II aleveolar epithelial cells. Biochim Biophys Acta. 530, 197-207

44 Mason, R. and Williams, M. (1977) Type II alveolar cell. Defender of the alveolus. Am Rev Respir Dis. 115, 81-91 


\section{FIGURE LEGENDS}

Figure 1 Intracellular distribution of $R_{\mathrm{L}} 8$-Alexa488 and Alexa488-Tf in suspension cells. $\mathrm{KG1a}, \mathrm{KG} 1$ and $\mathrm{K} 562$ cells were incubated at 37 or $4^{\circ} \mathrm{C}$ with 2 or $5 \mu \mathrm{M} \mathrm{R}_{\mathrm{L}} 8$-Alexa488 or $100 \mathrm{nM}$ Alexa488-Tf for $1 \mathrm{~h}$ before washing and analysis by confocal microscopy. Images are of 20 individual sections through the z-axis that were overlayed to generate maximum projection profiles. Single sections through the cells are shown as Supplementary Figure 1. Arrows indicate cytoplasmic labelling and inlay in $2 \mu \mathrm{M} \mathrm{K} 562$ cells at $37^{\circ} \mathrm{C}$ shows direct interference contrast images of cells overlayed with fluorescent images. Scale bars $10 \mu \mathrm{m}$.

Figure 2 Time-lapse microscopy of $R_{\mathrm{L}} 8$-Alexa488 uptake in KG1a cells.

Cells were incubated with 2 or $10 \mu \mathrm{M} \mathrm{R}_{\mathrm{L}} 8$-Alexa488 and immediately analysed by timelapse confocal microscopy. Frames were recorded every 30 seconds for 10 min and images representing cellular fluorescence and bright field profiles immediately following peptide addition (0) and after 5 and $10 \mathrm{~min}$. Time-lapse movies covering the $10 \mathrm{~min}$ imaging period for the entire field of view and depicted cropped region are shown as Supplementary Movies 1-4. Scale bars $10 \mu \mathrm{m}$.

Figure 3 Cellular distribution of $R_{L} 8$-Alexa488 and Alexa488-Tf in HeLa and A549 cells.

(A) HeLa and A549 cells were incubated at 37 or $4{ }^{\circ} \mathrm{C}$ with 2 or $5 \mu \mathrm{M} \mathrm{R}_{\mathrm{L}} 8$-Alexa488 or 100 $\mathrm{nM}$ Alexa488-Tf for $1 \mathrm{~h}$ before washing and analysis by confocal microscopy. (B) HeLa and A549 cells were incubated at 37 or $4^{\circ} \mathrm{C}$ with $20 \mu \mathrm{M} \mathrm{R}_{\mathrm{L}} 8$-Alexa488 for $1 \mathrm{~h}$ before washing and analysis by confocal microscopy. Images shown are of 20 individual sections through the $\mathrm{z}$-axis that were overlayed to generate maximum projection images. Arrows show plasma membrane labelling. Scale bars $10 \mu \mathrm{m}$.

Figure 4 Quantification of $R_{L} 8$-Alexa488 uptake at different temperatures in suspension and adherent cells.

Suspension (A-B) or adherent (C-D) cells were incubated for $1 \mathrm{~h}$ with $1-5 \mu \mathrm{M} \mathrm{R}_{\mathrm{L}} 8$ Alexa488 at $37(\mathrm{~A}, \mathrm{C})$ or $4^{\circ} \mathrm{C}(\mathrm{B}, \mathrm{D})$ prior to washing and quantifying peptide uptake by flow cytometry. Graphs represent the geometric means \pm SD from 3 separate experiments performed in duplicate. Low and High in B represent fluorescence means of two cell populations that are observed in suspension cells under these conditions (See Figure 5B).

Figure 5 Cellular fluorescence profiles following $R_{L} 8$-Alexa488 uptake in suspension and adherent cells.

Suspension (A-B) or adherent (C-D) cells were incubated for $1 \mathrm{~h}$ with $1-5 \mu \mathrm{M} \mathrm{R}_{\mathrm{L}} 8$ Alexa488 at $37(\mathrm{~A}, \mathrm{C})$ or $4^{\circ} \mathrm{C}(\mathrm{B}, \mathrm{D})$ prior to washing and quantifying peptide uptake by flow cytometry. Suspension cells incubated at $37^{\circ} \mathrm{C}$ with the peptide display a single peak of fluorescence (A) whilst those incubated at $4{ }^{\circ} \mathrm{C}$ display 2 peaks of fluorescence designated Low and High (Figure 4B).

Figure 6 Effects of cholesterol depletion on the intracellular distribution and uptake of $\mathbf{R}_{\mathrm{L}} 8$-Alexa488.

Cells were pre-incubated for $30 \mathrm{~min}$ in the absence (Control) or presence (M $\beta C D$ ) of $5 \mathrm{mM}$ $\mathrm{M} \beta C D$ prior to washing and incubation for $1 \mathrm{~h}$ with $2 \mu \mathrm{M} \mathrm{R} \mathrm{R}_{\mathrm{L}} 8$-Alexa488. The cells were analysed by confocal microscopy (A), or flow cytometry (B). (A) Images shown are from 20 individual sections through the $\mathrm{z}$-axis to generate maximum projection profiles. Scale bars 10 $\mu \mathrm{m}$. (B) fluorescence of control cells was set to $100 \%$. Statistical analysis for comparing the 
uptake of $\mathrm{R}_{\mathrm{L}} 8$-Alexa488 in untreated cells compared with uptake in $\mathrm{M} \beta \mathrm{CD}$ treated cells was performed using Student's t test. ${ }^{* *} \mathrm{P}<0.01$; decreased relative to control.

Figure 7 Effects of cholesterol depletion on the uptake of $R_{L} 8$-Alexa488 in KG1a cells at $4^{\circ} \mathrm{C}$.

Cells were pre-incubated for $30 \mathrm{~min}$ in the absence (Control) or presence (M $\beta C D)$ of $5 \mathrm{mM}$ $\mathrm{M} \beta C D$ at $37^{\circ} \mathrm{C}$, prior to washing and incubation for $1 \mathrm{~h}$ with $2 \mu \mathrm{M} \mathrm{R} \mathrm{R}_{\mathrm{L}} 8$-Alexa 488 at $44^{\circ} \mathrm{C}$. Cells were washed and immediately analysed by flow cytometry. Values above the peaks indicate the percentage of the total cell population in each peak area obtained from 3 experiments performed in duplicate. Overlay - Untreated = Black line; Control = Black fill; $\mathrm{M} \beta \mathrm{CD}=$ Grey line

Figure 8 Effects of cholesterol replenishment on the uptake of $R_{L} 8$-Alexa488 in KG1a cells.

(A-D) KG1a cells were incubated under conditions described in Table 1 prior to analysis of $\mathrm{R}_{\mathrm{L}} 8$-Alexa488 uptake at $4^{\circ} \mathrm{C}$ by flow cytometry (left column) or Filipin staining (right column). Values above the peaks indicate the percentage of the total cell population in each peak area. Data are from one representative experiment, each experiment was performed three times in duplicate. Scale bars $10 \mu \mathrm{m}$. E Quantification of Filipin fluorescence. Results are normalised to control cells (100\%), Statistical analysis for comparing Filipin fluorescence was performed using one way ANOVA followed by a Dunnetts post hoc test. ${ }^{* *} \mathrm{P}<0.01$; statistically different to control cells. 
Watkins et al. Table 1

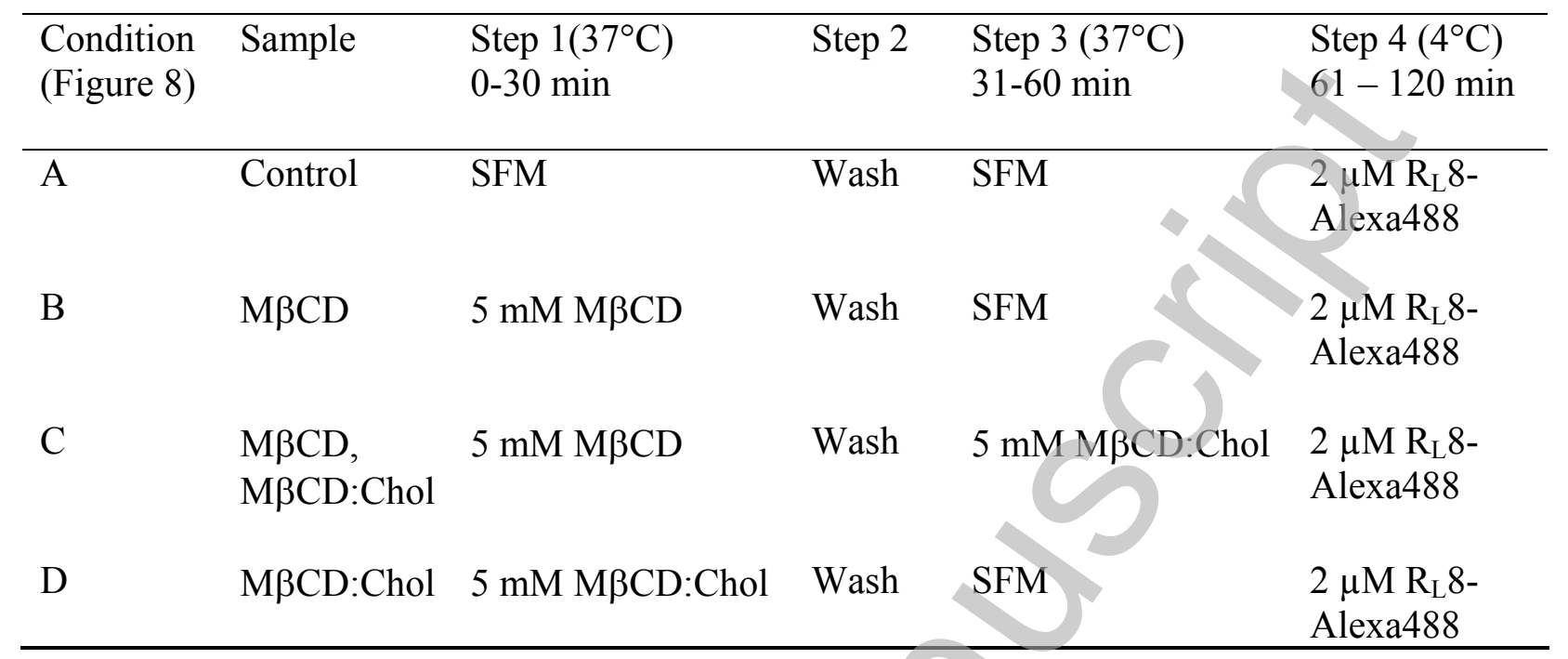

Table 1 Incubation steps for cells treated with M $\beta C D$ and/or M $\beta C D$ :Cholesterol complexes to generate Figure 8. 
Watkins et al. Figure 1

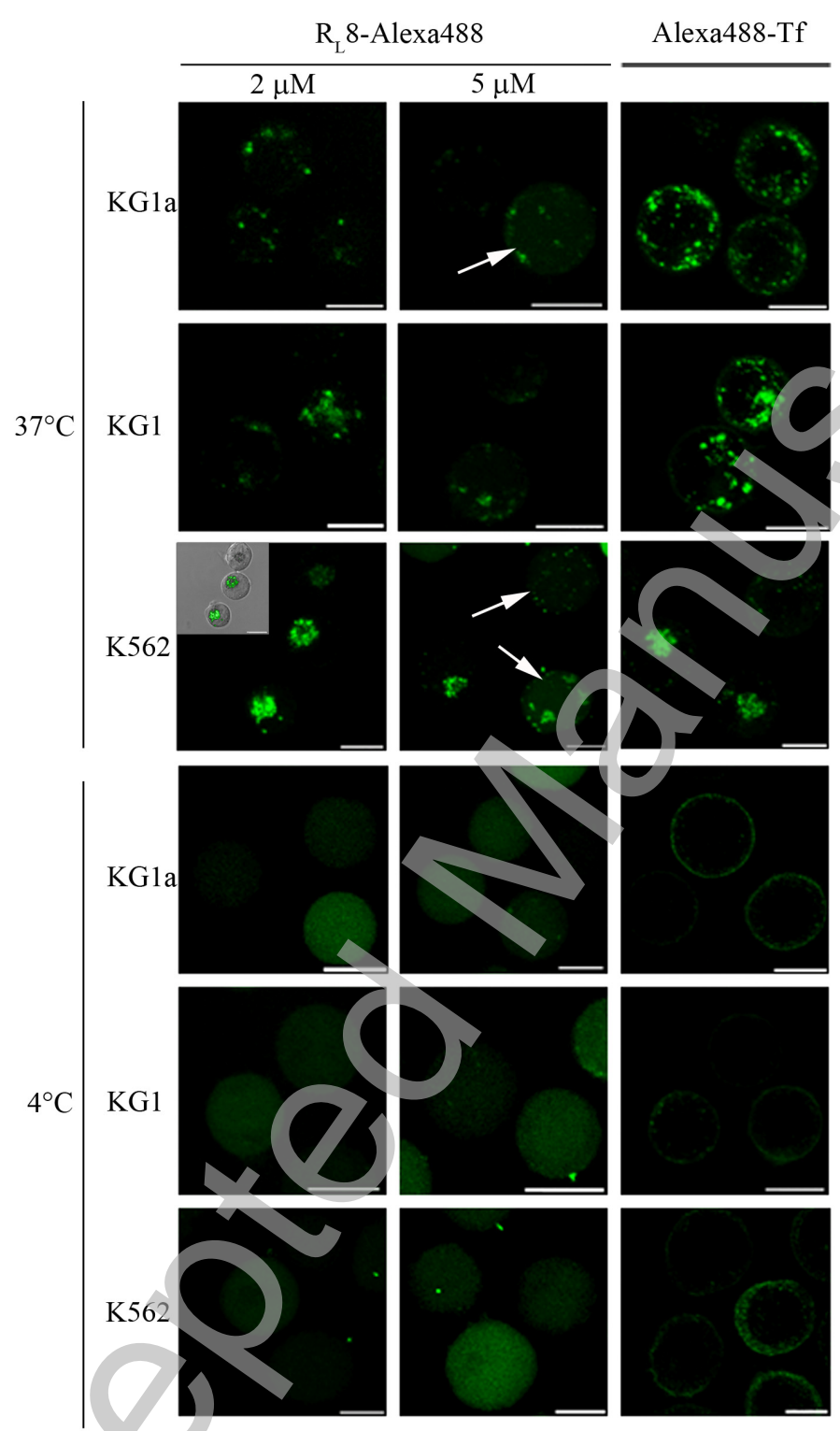


Biochemical Journal Immediate Publication. Published on 13 Feb 2009 as manuscript BJ20090042

Watkins et al Figure 2
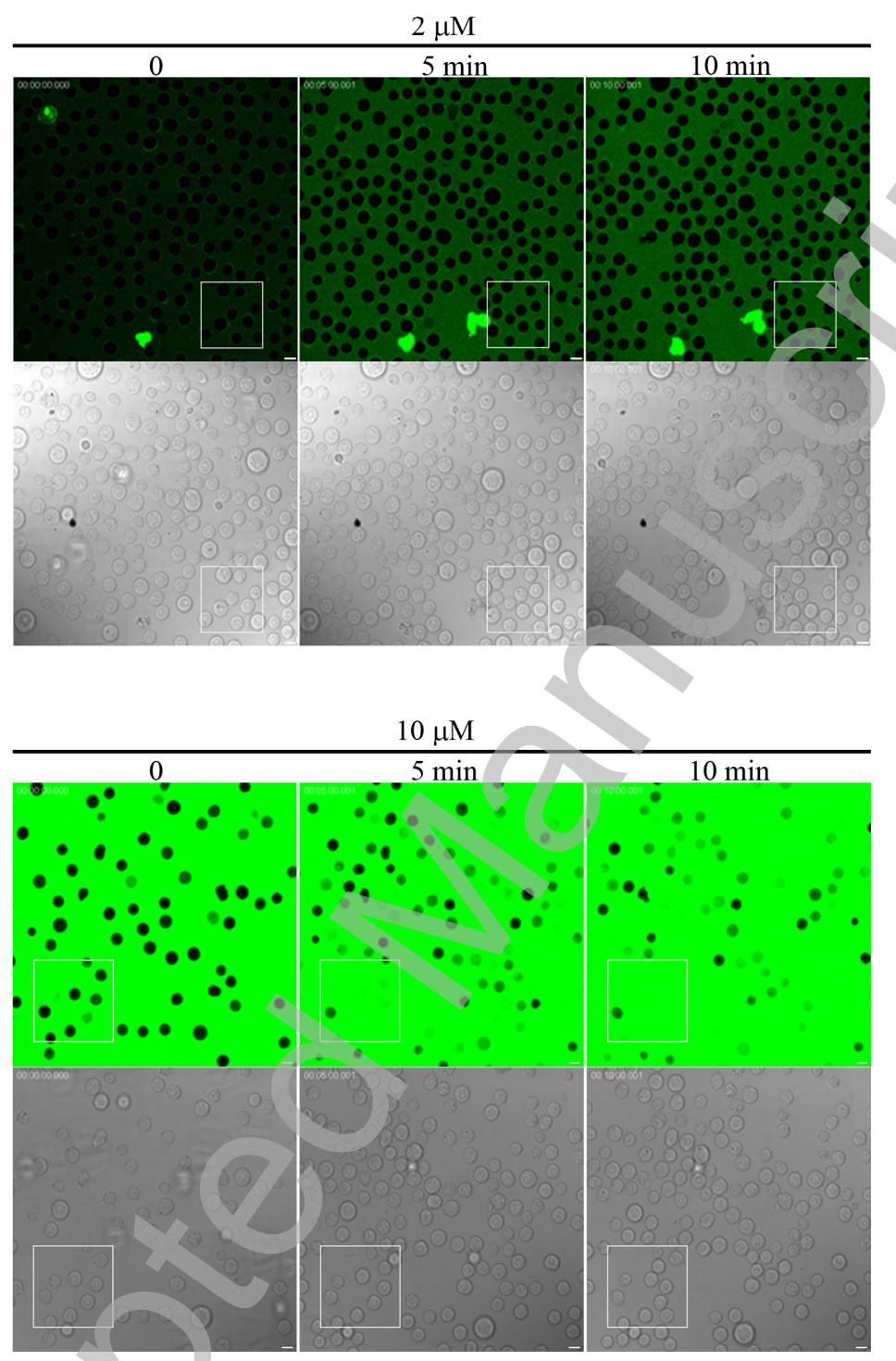

Licenced copy. Copying is not permitted, except with prior permission and as allowed by law. (C) 2009 The Authors Journal compilation (c) 2009 Portland Press Limited 
A.

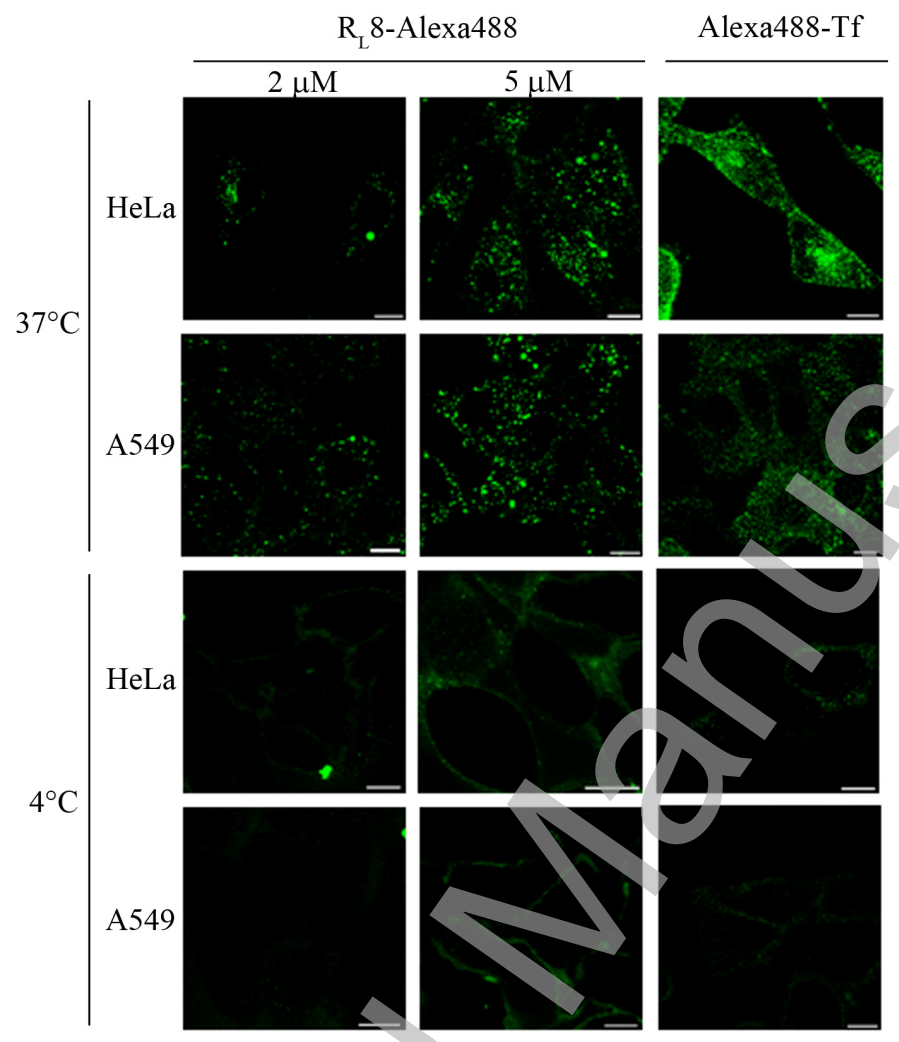

B.

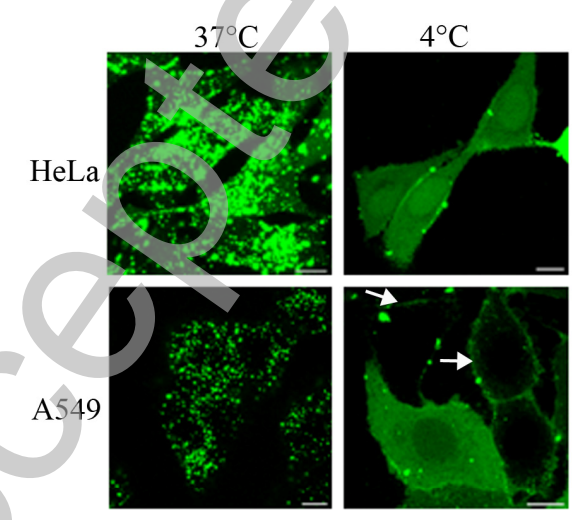



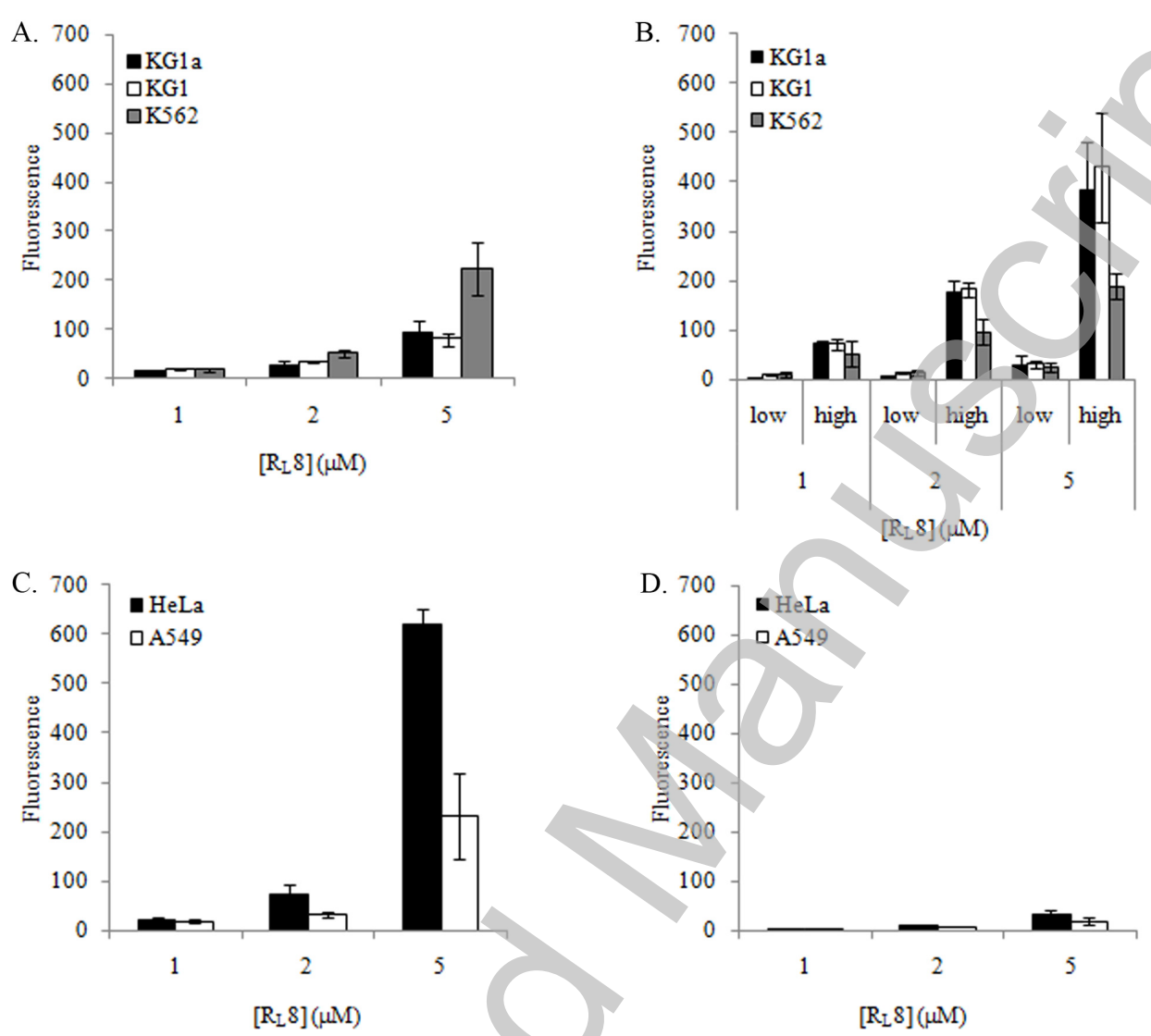


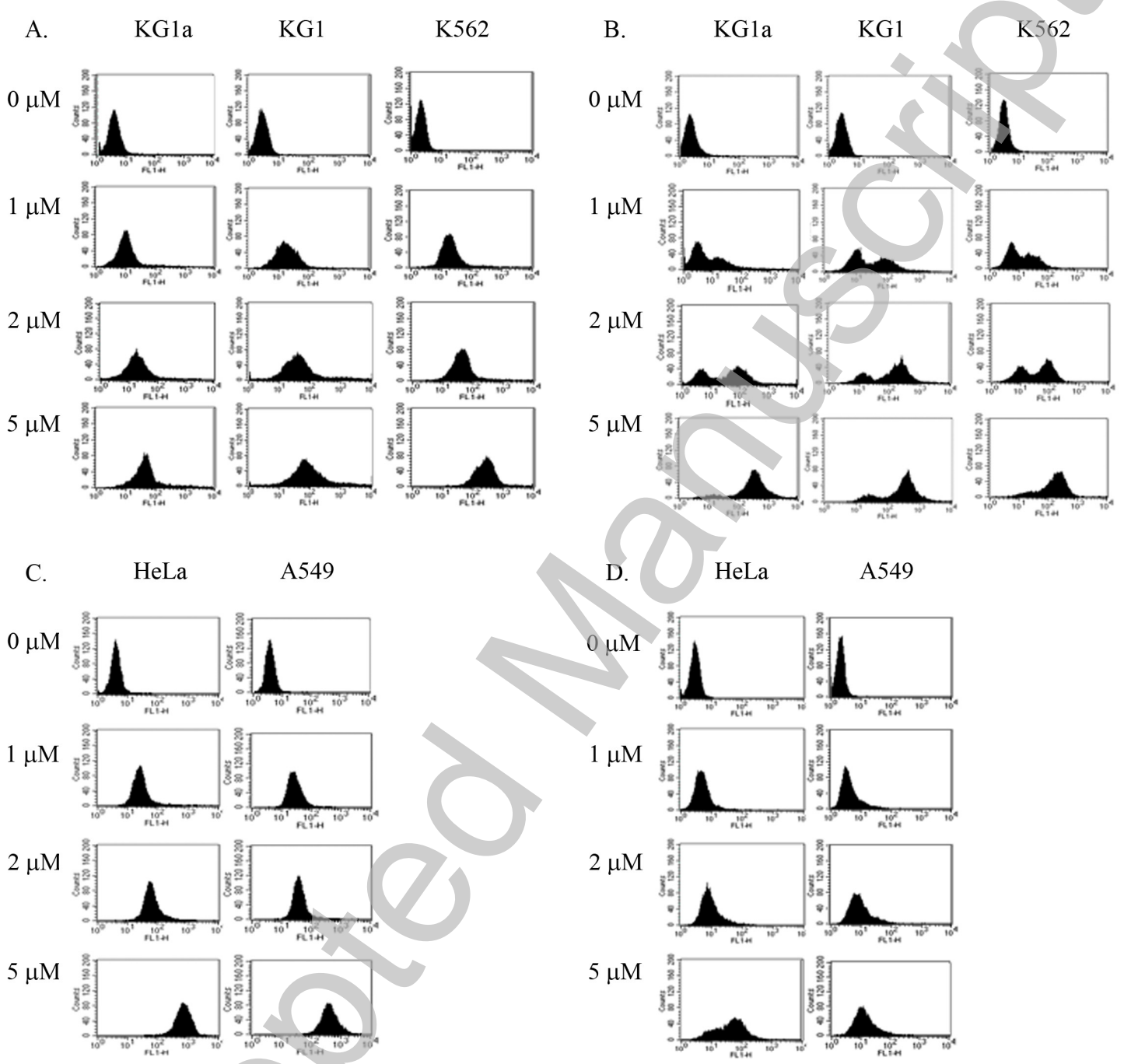




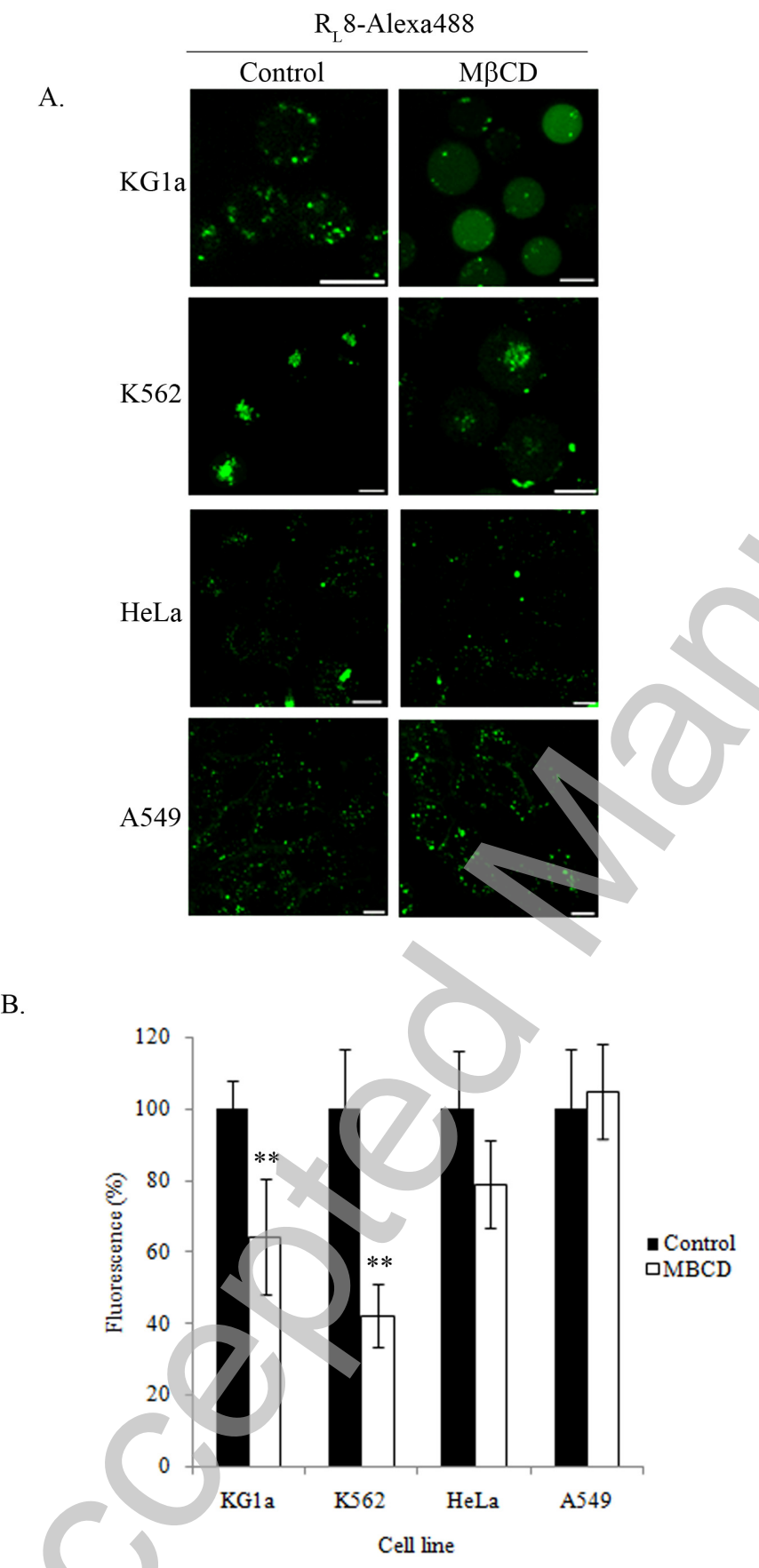



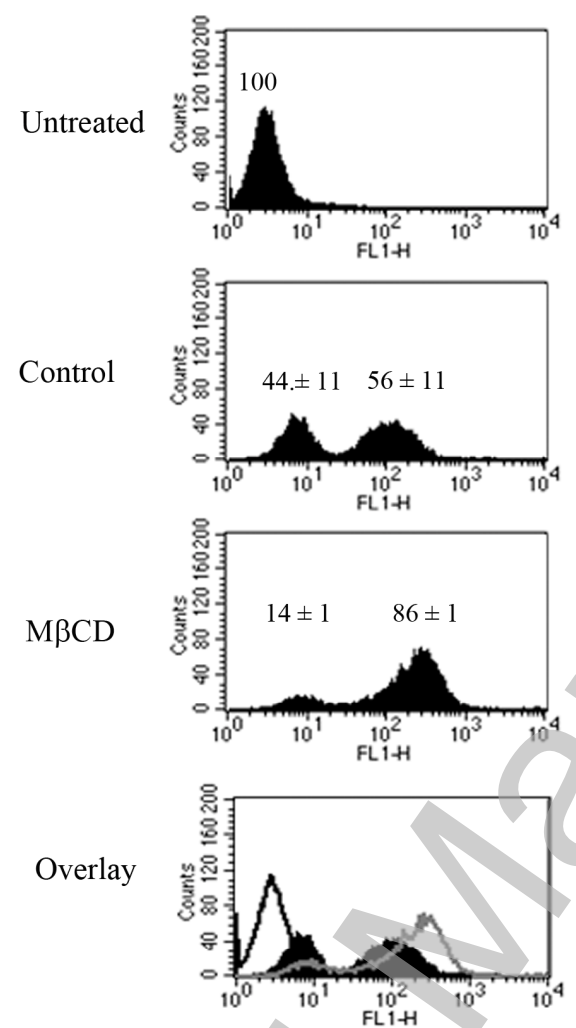

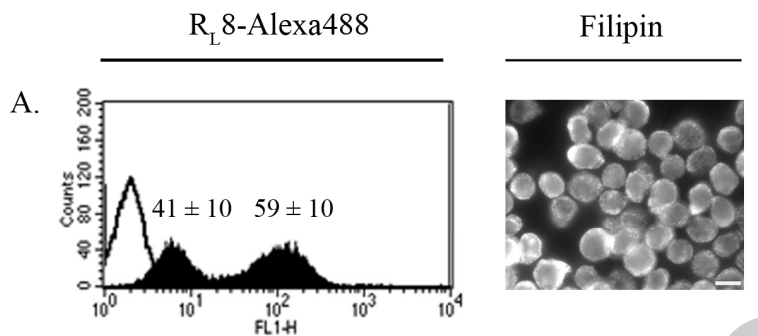

B.
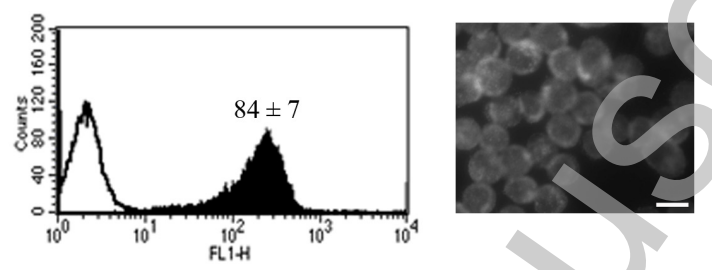

C.
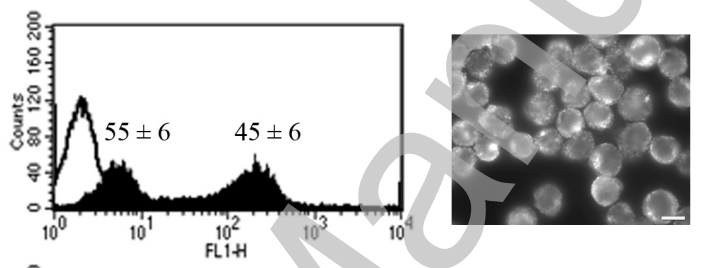

D.
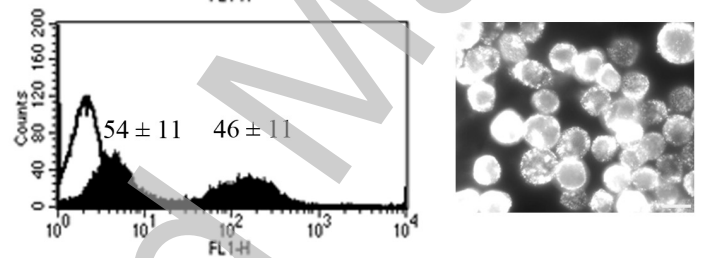

E.

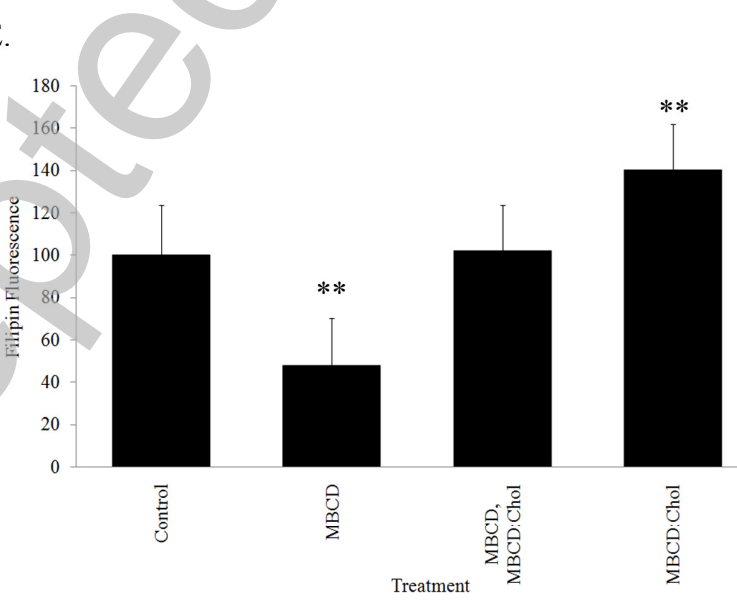

